\title{
建築用仕上塗材の吹付工法に影響を及ぼす吹付ガン器の メカニズムについて \\ MECHANISM OF SPRAY GUN INFLUENCED ON SPRAY METHOD OF SPRAYINGS
}

\author{
在永末徳, 村永和生 ${ }^{* *}$, 佐治泰次*** \\ Suenori ARINAGA, Kazuo MURANAGA and Taiji SAJI
}

\begin{abstract}
The weight of sprayings by spray gun is one of the most important factors on the workability of sprayings. In this paper, the suitable weight of sprayings by spray gun and many spray factors were examined experimentally and the equation of the weight of sprayings by spray gun was proposed theoritically.

The following results were drawn from this study.

1) The maximum weight of sprayings is decided by the best efficent type in three jet types of spray gun.

2) The air pressure which produced the maximum weight of sprayings agrees with the most suitable spraying presure on many sprayings.

3) The flow quantity of compressed air increase with increasing the viscosity of sprayings.

4) The opening rate of nozzle does not influence on the weight of sprayings by spray gun, but influences on the corpuscle of sprayings which have effects on the texture of spray finishing.

5) The proposal equation by applying the jet theory agress, with the experimental value of the weight of sprayings by spraying gun.
\end{abstract}

Keywords : spray gun, sprayings, compressed air, texure, jet theory

\section{1.はじめに}

建築用仕上塗材の吹付工事は, 塗装・内装工事等とと もに建築物の最終仕上工程の良否によって，その仕上げ 性能が左右される。したがって、メーカーによる材料の 品質管理だけでなく，施工上の技術管理が重要視される ことになる。また，吹付工事は躯体工事や他の仕上工事 の進行状況にも影響を受け，作業環境や作業条件は極め て複雑となり，実際の吹付作業は施工管理担当者や吹付 技術者が直接に判断しなければならない場合が多い。そ こで，伝統的な技術さ経験や勘に支えられてきた従来の 吹付工法に対して，理論的かつ実験的な検討を行い，新 しい吹付工法として, システム化していく必要性がでて きた。この場合, 吹付ガン器からの吹出量を制御し, 吹 付け仕上げ面のテクスチャーを決定することは，吹付工 法の中心的課題となる。

本研究は, 吹付工法に熟達した技術者が, 経験と勘に 頼って発展させてきた吹付工法（特に, 吹付ガン器の使
用方法）を，理論的かつ実験的に明らかにし，より合理 的な吹付工法の開発を試みようとしたものである。まず, 吹出量が吹付ガン器の運行速度や吹付厚さに大きな影響 を及ぼすことから，吹付ガン器の噴流形式を口金径と，

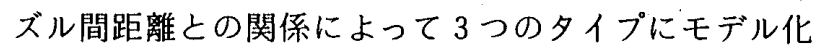
し，最適吹出量を実験的に決定する方法を提案する。ま た，どのような吹付要因が吹出量に影響を及ぼすかにつ いても実験的に検討する。しかし, 最近のように, 吹付 工法の自動化・機械化が志向されている中では, 吹付ガ ン器の吹出量を実験的に解明するだけでなく，吹出量を 規定する要因を理論的に明らかにすることが必要であ る。そこで, 実験から得られた知見を基に, 吹付ガン器 の吹付過程に気液二相の噴流理論を適用し, 吹出量に影 響を及ぼす各種吹付要因を解析した。

\section{2. 吹付ガン器の噴流形式}

我が国で開発された欦付ガン器は，カップまたはホッ

\footnotetext{
* 近畿大学 助教授.工博

** 近畿大学 教授

*** 九州大学 名誉教授.工博
}

Associate Professor of Kinki University, Dr. Eng.

Professor of Kinki University

Emeritus Professor of Kyusyu University, Dr. Eng. 


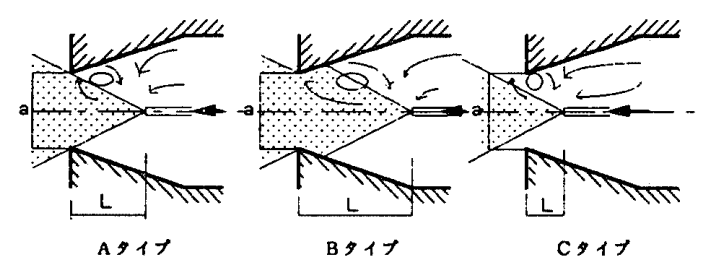

図一2.1吹付ガン器の噴流形式

パと圧縮空気を噴射させるノズルとを組み合わせた簡単 なガン器であり，口金近傍で吹付材と圧縮空気を混合し 吹き出させるものである。多くは軽合金で出来ており， ホッパがスプレーの上に付いている自重式とカップがス プレーの下に付いている吸上式とがある。建築用仕上塗 材に使用される吹付ガン器は自重式が多く, 吹付材の吹 出量は, その吹付ガン器の構造によって左右される。吹 付ガン器は図一 2.1 に示すように, 口金径 $a$ と口金先端 からノズル先端までの長さを示すノズル間距離 $L$ との 関係によって噴流状態が異なり, 主に3つの噴流形式に 分けてモデル化することができる。

Aタイプは，噴流の広がりが口金の位置でちょうどロ 金径 $a$ と一致し，吹付材が最も効率よく吹き出される ものと推定される。Bタイプは, 口金径 $a$ に比べてノ ズル間距離 $L$ が長すぎる場合で，噴流が壁面に衝突し 大きな壁面摩擦を受けながら吹き出されるものと考えら れる。Cタイプは, ノズル間距離 $L$ が短すぎる場合で, ホッパからの吸込量が不足し，吹出効率の低下が予想さ れる。

本論ではこの 3 形式のうちAタイプを基本形式として 主に検討した。

\section{3. 実験方法}

\section{1 使用材料と使用ガン器}

本実験に使用した材料は, 通称, 樹脂リシン・樹脂夕 イル・樹脂スタッコと呼ばれる 3 種類のエマルション系 の建築用仕上塗材（以下，吹付材という）である。骨材 として,リシンには $1 \mathrm{~m} / \mathrm{m}$, スタッコには $1.5 \mathrm{~m} / \mathrm{m} の$ 粒状大理石を使用した。また，メーカー製造の吹付材の ベース基材に対する混練水の重量比を水比 $X$, 骨材の 重量比を骨材比 $Y$ と定義すれば，調合の種類は，リシ ンでは水比 $X=7 \%$ について, 骨材比 $Y=100 \%$, 水 比 $X=10 \%$ については骨材比 $Y=80,100,120 \%$ の 3 種類, 水比 $X=13 \%$ につては骨材比 $Y=100 \%$ の計 5 種類である。吹付タイルでは水比 $X=1.5,2.0,3.0$ $\%$ の 3 種類であり, スタッコでは水比 $X=1.5 \%$ につ いては骨材比 $Y=70,90,110 \%$ の 3 種類, 水比 $X=$ $3.0 \%$ については骨材比 $Y=90 \%$, 水比 $X=4.5 \%$ に ついては骨材比 $Y=90 \%$ の計 5 種類である。使用した 吹付ガン器は固定ガン器と万能ガン器の 2 種類である。 ただし固定ガン器は一種のリシン専用ガン器であり,リ
シンに対してのみ使用した。

\section{2 ホッパ流量の測定}

ホッパから吹出口に自重によって吐出される吹付材の 流量をホッパ流量 $M_{a}$ と定義する。ホッパ流量は吹付ガ ン器の口金をはずすことによって，全ホッパ容積の 80 \%ほど入れた吹付材を，一定時間間隔ごとにビニール 袋に流出させ,その重量を測定することによって求めた。 全ホッバ容積は固定ガン器で $1.6 l$, 万能ガン器で $2.5 l$ であり，計測には電子天秤を用いた。なお，スタッコは 粘性が極めて大きく，吐出量が少なかったので，ホッパ 流量は無視し検討を行った。

\section{3 吹出量の測定}

吹出量 $M_{e}$ の測定は，吹出量に影響を及ぼすと予想さ れる吹付材の水比 $X$ ・骨材比 $Y$ や口金径 $b_{s} \cdot$ ’ズルロ 径 $a$, コンプレッサーの吹付圧力 $P \cdot$ 空気流量 $Q_{s} \cdot$ ， ズル開口率 $R$ 等の各種吹付要因の水準を変化させ, 吹 付材をビニール袋の中に一定時間間隔ごとに吹き出し， 袋の中の吹付材の重量を測定する方法によった。測定は それぞれの吹出量の経時的変化を求めるために，ホッパ 内の吹付材が無くなるまで続け，ホッパ流量の測定と同 様に電子天科を用いた。

\section{4 空気流量の測定}

コンプレッサーによる空気流量 $Q_{s}$ の測定は, 図一 3.1 に示すように, 水槽の中のポリエチレン製容器内に ノズルの先端に付けたゴムホースを挿入し, 容器内の空

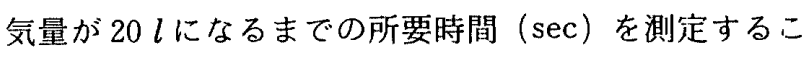
とによって求めた。測定項目およびその水準は, 空気流 量 $Q_{s}$ に影響すると考えられるノズル口径 $b_{s}$ ・欣付圧力 $P$ ・ノズル開口率 $R$ の組み合わせによる 16 種類で古 る。

\section{4. 最適吹出量の決定}

4.1 全吹出量の経封的変化

本実験で使用した 3 種類の吹付材の全吹出量 $W$ の経 時的変化は, 吹付材の種類にかかわらずほぼ同様の傾向 を示す。ここでは, 固定ガン器による樹脂リシンの場合 について図一 4.1 に示したが, それによると, 各吹付材 とも全吹出量の $90 \%$ 位まではおおむね直線的に変化し ていることがわかる。このことはホッパ内の吹付材がほ

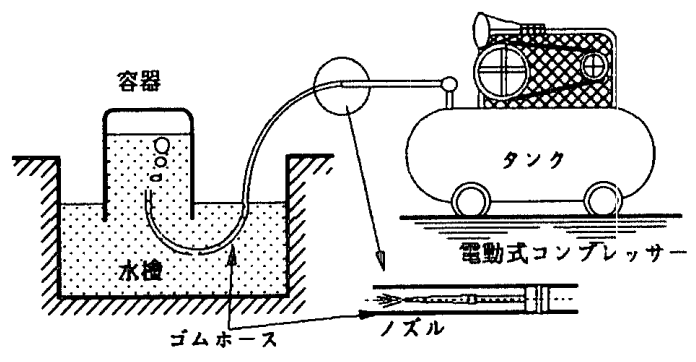

図一3.1 空気流量の測定 


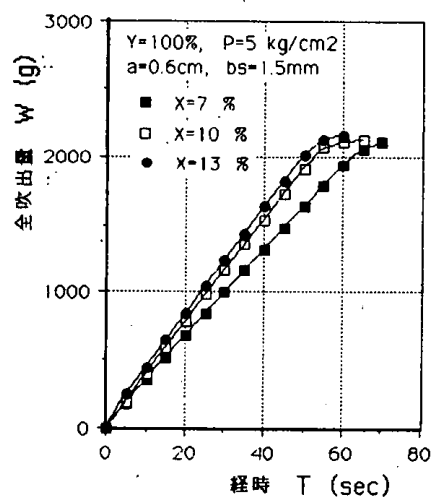

図一4.1 全吹出量 $W$ の経時的変化

ぼ空になるまでは安定的に吹付作業が可能であることを 示し，吹きむらを防ぎ，吹付面を平滑に仕上げるうえで 重要な要素となっている。

\section{2 決定方法}

吹付ガン器の噴流形式は, 口金径 $a$ とノズル間距離

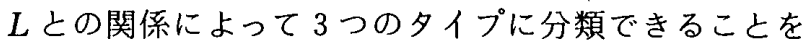
述べた。ここでは，基本形式である A夕イプを実験的に 推定する方法について述べる。まず，各吹付材の全吹出 量 $W$ の流量変化を吹出量 $M_{e}$ と定義する。リシン・吹 付タイル・スタッコの 3 種類の場合について, 吹出量 $M_{e}$ とパラメータ $a / 2 L$ との関係を示したのが図一 4.2 である。それによると，各吹付材とも同様の傾向を示し， 吹出量 $M_{e}$ は $a / 2 L$ の大きさによって最大值と $2 つ$ 直 線部分之に分けられることが分かる。そこで図一 4.3 を 用いてその物理的意味について検討する。図中の 2 直線 の交点は最大の吹出量を示し, 吹出効率の最もよい噴流 形式のAタイプに相当する。ここで，この交点の $a / 2 L$ を噴流開度 $K$ と呼ぶことにする。また， $a / 2 L$ が噴流 開度 $K$ より大きい場合はCタイプに相当し，噴流開度 $K$ より小さい場合は B夕イプに相当する。このように， パラメータ $a / 2 L$ を変化させ, 求められた吹出量を各 タイプごとに直線で示し，その交点を求めれば最大吹出 量が決定される。ちなみに，Aタイプの噴流形式が，現 場の吹付技術とよ゙のような関係にあるかを調べるため に，現場施工経験 5 年を有する吹付技術者に，通常の操 作で実際に吹付け作業を行ってもらい，使用する吹付ガ ン器の噴流開度 $K=a / 2 L$ を検討した。その結果, 経 験と勘とに基づいて開発された吹付技術ではあるが，ほ ぼAタイプの近傍で操作されていることが分かった。ま た，表一 4.1 には，本実験で得られた各吹付ガン器の噴 流開度 $K$ を示した。それによると，噴流開度 $K$ は吹付 ガン器や吹付材の種類に対して極めて敏感であるが，吹 付材の調合にはほとんど影響を受けないことが分かっ た。

以上から, 吹出量 $M_{e}$ の最大値を持つAタイプを理想 的な吹付け状態とみなし，最適吹出量を実験的に決定す


図-4.2 吹出量 $M_{e}$ と $a / 2 L$ の関係

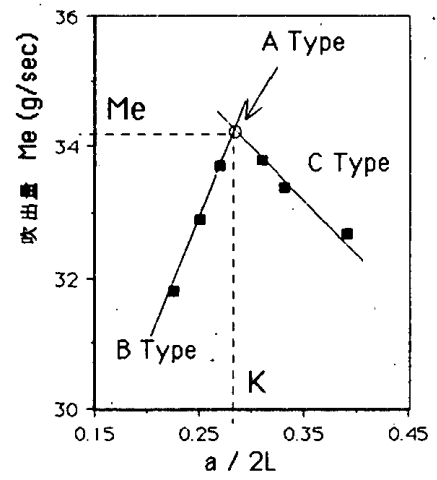

図一 4.3 最適吹出量の決定方法

表一4.1 各吹付ガン器の噴流開度

\begin{tabular}{|c|c|c|c|c|c|}
\hline \multirow{2}{*}{ 使用材料 } & \multirow{2}{*}{ 使用カン器 } & \multicolumn{2}{|c|}{ 周合比 $(\%)$} & \multirow{2}{*}{ 噴流開度 K } & \multirow{2}{*}{$\begin{array}{c}\text { 最適吹出重 } \\
\text { Me } \\
(\mathrm{g} / \mathrm{sec})\end{array}$} \\
\hline & & 水比 $\mathrm{X}$ & 目材比 Y & & \\
\hline \multirow{2}{*}{ リシン } & 固定ガン器 & $\begin{array}{c}7 \\
10\end{array}$ & \multirow{2}{*}{100} & $\begin{array}{l}0.282 \\
0.286\end{array}$ & $\begin{array}{l}34.11 \\
39.05\end{array}$ \\
\hline & \multirow{3}{*}{ 万能カン器 } & $\begin{array}{c}7 \\
10 \\
13\end{array}$ & & $\begin{array}{l}0.178 \\
0.187 \\
0.185\end{array}$ & $\begin{array}{l}41.00 \\
42.00 \\
47.67 \\
50.63\end{array}$ \\
\hline 吹付タイル & & $\begin{array}{c}1.5 \\
2.5 \\
3\end{array}$ & 0 & $\begin{array}{l}0.108 \\
0.108 \\
0.106 \\
0.108\end{array}$ & $\begin{array}{l}60.00 \\
66.00 \\
74.47 \\
74.55\end{array}$ \\
\hline スタッコ & & $\begin{array}{l}3 \\
3 \\
4.5\end{array}$ & 90 & $\begin{array}{c}0.199 \\
0.2\end{array}$ & $\begin{array}{l}53.22 \\
62.14\end{array}$ \\
\hline
\end{tabular}

ることができる。

\section{5. 吹出量 $\boldsymbol{M}_{e}$ に及ぼす吹付要因の影響}

5.1 水 比

メーカ一製造の各吹付材のベース基材を水比 $X=0.0$ の吹付材とみなすが，そのままでは粘性が大きく実用的 でない。そこで, ベース基材に水を加え，適度な粘性を 持った吹付材に調合すれば，それに伴い吹出量 $M_{e}$ が増 加する。その様子を各吹付材について示したのが図一 5.1 である。それによると，粘性の小さいリシンや吹付 タイルは水比 $X$ が大きくなるにつれて吹出量が増大す る傾向を示す。一般に，吹付ガン器の吹出量は，自重に よって吹出口に搬送されるホッパ流量 $M_{a}$ と空気噴流に よって吹出口に搬送される吸込流量 $M_{r}$ に影響されるこ とからこれらの傾向は容易に予測できる。ところが， 粘性の大きいスタッコは, 水比に影響されずほぼ一定値 


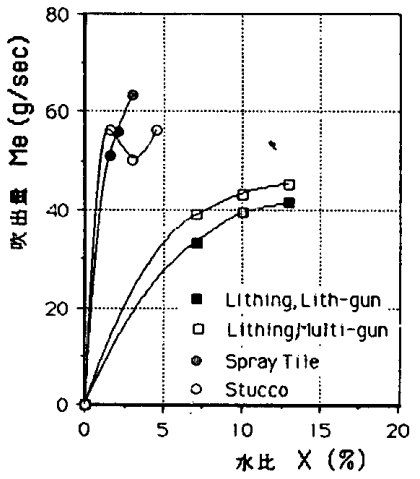

図一5.1 吹出量 $M_{e}$ と水比 $X$ との関係

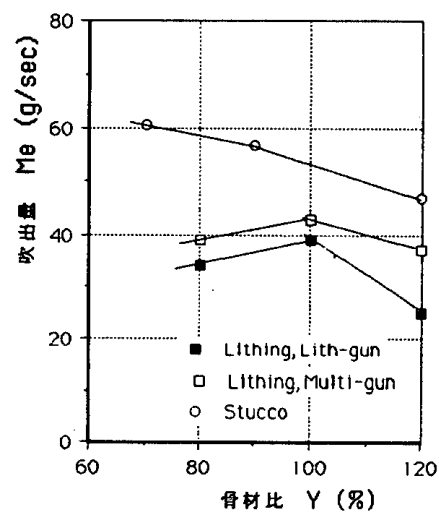

図-5.2 吹出壘 $M_{e}$ と骨材比 $Y$ との関係

を示す。このことは, スタッコの場合，ホッパ流量はほ とんビゼロに近いため，吹出量が吸込流量のみに影響さ れることから理解できる。

\section{2 骨材比}

一般に，吹付材の水比が大きくなれば粘性が小さくな り，吹出量 $M_{e}$ が大きくなることは容易に予測できる。 しかし, 骨材比 $Y$ が変化した場合, 基材の粘性によっ て異なった挙動を示す。その様子を図一5.2 に示す。そ れによると，リシンのように粘性の小さい吹付材は，使 用した吹付ガン器に関係なく吹出量が最大になる骨材比 が存在するが, スタッコのように粘性の大きい吹付材は, 骨材比が大きくなるにつれて吹出量は小さくなる。これ は，吹出量がホッパ流量と吸込流量の影響を受けるが, 粘性が大きければ，吸込流量のみに影響されることによ ると考えられる。

\section{3 口金径}

吹付ガン器の口金径 $a$ はリシン・吹付タイル・ス タッコなど各吹付材に応じて使い分けられている。一般 に,リシンの場合 $4 \sim 6 \mathrm{~m} / \mathrm{m}$, 吹付タイルでは $6 \sim 8 \mathrm{~m} / \mathrm{m}$, スタッコでは 8 $12 \mathrm{~m} / \mathrm{m}$ が標準口径として多く用いら れている。図一5.3 には各吹付材の吹出量 $M_{e}$ と口金径 $a$ との関係を示すが, 全体として, 各吹付材とも緩やか な S字形の曲線を描くことが分かる。しかも，各吹付材 ともその標準口径が反曲点の近傍に位置し，Aタイプに 近い状態にあることを示している。

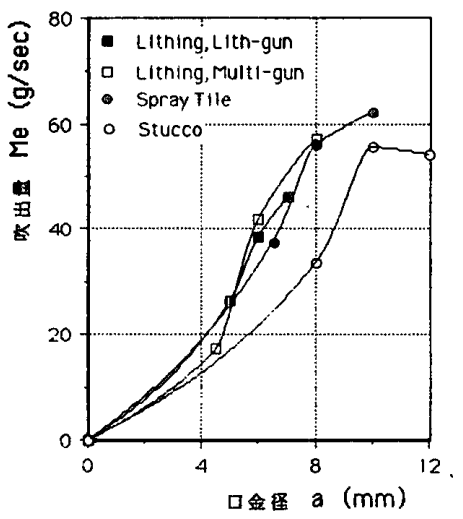

図一5.3 吹出脰 $M_{e}$ と口金径 $a$ との関係

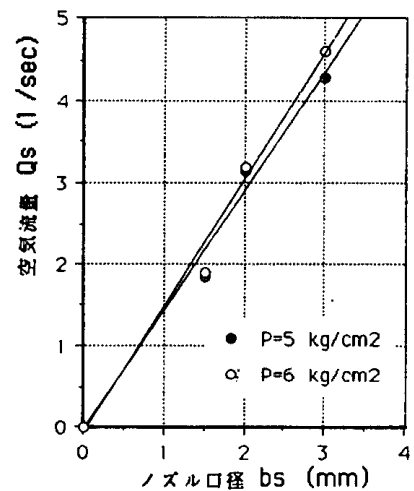

図一5.4 空気流量 $Q_{s}$ とノズル口径 $b_{s}$ との関係

\section{4 空気流量とノズル口径}

吹付材はノズルからの圧縮空気によって吹き出される ため, 空気流量 $Q_{s}$ が吹出量 $M_{e}$ に大きな影響を及ぼす。 図一5.4 に示すように，ノズルからの空気流量はノズル 口径 $b_{s}$ にほぼ比例し, 吹付圧力 $P=5 \sim 6 \mathrm{~kg} / \mathrm{cm}^{2}$ の蝺 囲内ではほとんど等しい空気流量を示す。このことから， 図一 5.5 に示すように, 吹出量 $M_{e}$ とノズル口径 $b_{s}$ 之 の関係から空気流量の影響も同時に推定できる。ノズル 口径 $b_{s}$ が大きくなると空気流量も大きくなるので，リ シンのように粘性の小さい吹付材は，比較的小さい空気 流量で吹付け施工が可能であり，逆に，空気流量が多す ぎると吹出量は減少する傾向にあるため，ノズル口径 $b_{s}=1.5 \sim 2.0 \mathrm{~m} / \mathrm{m}$ 程度が最適である。中程度の粘性を 持つ吹付タイルの場合は，やや多くの空気流量を必要之

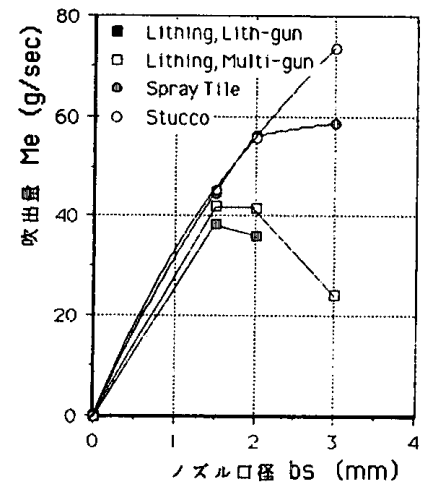

図一5.5 吹出量 $M_{e}$ とノズル口径 $b_{s}$ との関係 
し，少なくとも，ノズルロ径 $b_{s}=2 \mathrm{~m} / \mathrm{m}$ 程度のノズル が必要である。粘性の大きいスタッコの場合は，もっと 多くの空気流量を必要とし，ノズル口径 $b_{s}=3 \mathrm{~m} / \mathrm{m}$ 程 度のノズルが望まれる。

以上のように，粘性の大きな吹付材ほど多くの空気流 量 $Q_{s}$ を必要とし，口径の大きなノズルを用いる必要が ある。

\section{5 吹付圧力}

空気流量 $Q_{s}$ だけでなく吹付圧力 $P$ も吹出量 $M_{e}$ に影 響を及ぼす。その様子を図一5.6に示す。それによると， 各吹付材とも吹出量を最大にする吹付圧力が存在するこ とが分かる。例えば，リシンの場合，固定ガン器および 万能ガン器とも吹付圧力 $5 \mathrm{~kg} / \mathrm{cm}^{2}$ 近傍で最大値あるい は一定となり，吹付タイルの場合も吹付圧力 $5 \mathrm{~kg} / \mathrm{cm}^{2}$ 近傍で最大値を持つ。またスタッコの場合は, $6 \mathrm{~kg} / \mathrm{cm}^{2}$ を越えると吹出量はかなり低下する。一般には，リシン で $4 \sim 5 \mathrm{~kg} / \mathrm{cm}^{2}$, 吹付タイル・スタッコでは $5 \sim 6 \mathrm{~kg} /$ $\mathrm{cm}^{2}$ の吹付圧力で吹付け施工がされており，この吹出量 を基準として最適吹付圧力の推定が可能である。

\section{6 ノズル開口率}

一般に, 空気流量 $Q_{s}$ の調節はノズル口径 $b_{s}$ を変化 させる方法ではなく, 吹付ガン器に付いているエアー コックを開閉して，ノズルの開口率 $R$ を調整する方法 を取っている。しかも，この方法は噴流による吹付材の 微粒化が可能であり, 吹付タイルやスタッコの吹付仕上 げ面のテクスチャーを決定するのに有効である。そこで, 吹出量 $M_{e}$ とノズル開口率 $R$ との関係を検討したのが 図一5.7である。そ机よると，ノズル開口率が 0.25 1.0 の範囲では吹出量はほぼ一定であり,ノズル開口率 が吹出量に及ぼす影響は小さいことが分かる。このこと から，ノズル開口率を小さくすることは，吹付け施工効 率を低下させずに噴流開度 $K$ を大きくし，吹付材の微 粒化を促進することが可能になると考えられる。

\section{6. 基本形式への噴流過程の適用}

6.1 吹付ガン器の噴流過程

吹付工法における能率的な吹付施工や吹付面の仕上げ

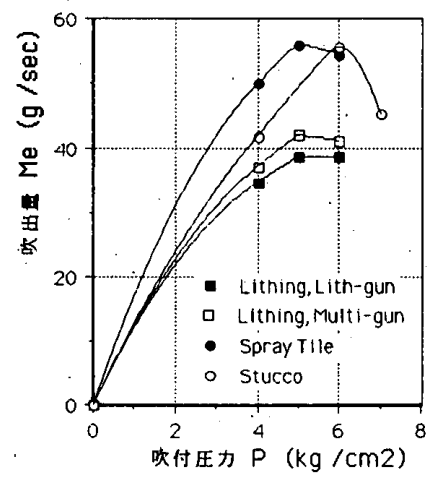

图一5.6 吹出量 $M_{e}$ と吹付圧力 $P$ 之の関係

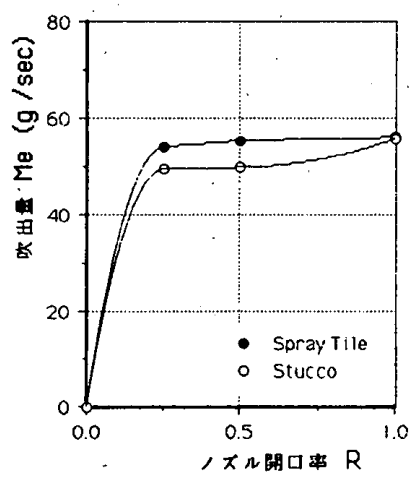

図一5.7 吹出量 $M_{e}$ とノズル開口率 $R$ との関係

性状は，吹付ガン器の構造に大きく左右される。けれど も, 吹付ガン器の構造は極めて単純なため, 過去におい て理論的・実験的な検討はほとんゼ行われず，吹付業者 や吹付技術者の経験に基づく工夫と試行錯誤によって改 善されてきた。しかし，構造は単純であろとも，取り扱 う吹付材は高粘度サスペンション粘性体であり，しかも， その中に圧縮空気を噴射させるため，気液二相の噴霧現 象を生じ，理論は決して単純ではない。一般に，吹付ガ ン器は自重によって吹出口に搬送されるホッパ流量と空 気噴流によって吹出口に搬送される吸込流量の影響を受 け，吹出量が決定される。

図一6.1 は, 吹付ガン器内の噴流過程をモデル化した ものである。吹付ガン器内に噴出される噴流のように， 囲いの中に噴出する噴流を制約噴流と呼び，壁面近傍に 再循環領域を作りながら吹付材を吸い込み，圧縮空気と ともに吹付材を吹き出す。吹付ガン器の噴流過程は，吹 付材が自重によって吹出口に搬送されるホッパ流量 $M_{a}$ と口金から噴出する吹付材の吹出量 $M_{e}$ との大小関係に よってつぎの 2 通りの場合が考えられる。

（i）吹出量 $M_{e}>$ ホッパ流量 $M_{a}$ の場合，口金近傍の 壁面の噴流境界との間に「循環渦」を形成する。

（2）吹出量 $M_{e}<$ ホッパ流量 $M_{a}$ の場合，噴流が口金 近傍の壁面に達するまでに，吹付材と圧縮空気との混合

(同伴) が十分に行われて「循環渦」を生じない。

そこで，一般的な同伴噴流の考え方に基づいて，吹出 量の混合方程式を次式のように仮定し，検討を行う。

$$
\frac{M_{r}}{M_{s}}=\alpha\left(\frac{\rho_{a}}{\rho_{s}}\right)^{1 / 2} \cdot \frac{X}{b_{s}}-1
$$

ここで, $M_{\tau}:$ 再循環流量 $(\mathrm{g} / \mathrm{sec})$

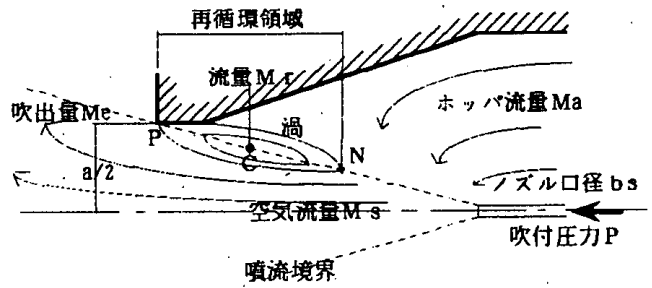

図一6.1，吹付ガン器内の噴流過程モデル 
$M_{s}:$ 空気流量 $(\mathrm{g} / \mathrm{sec})$

$\rho_{a}, \rho_{s}:$ 吹付材と圧縮空気の密度 $\left(\mathrm{g} / \mathrm{cm}^{3}\right)$

$X$ : 噴流軸方向距離 $(\mathrm{cm})$

$b_{s}:$ ノズル口径 $(\mathrm{cm})$

$\alpha:$ 実験定数

を示す。

また, 基本形式 ( Aタイプ) において, そのノズル間 距離 $L_{0}$ 亡噴流開度 $K$ との関係を考慮すれば,

$$
L_{0}=a / 2 K
$$

となる。

吹出量 $M_{e}>$ ホッパ流量 $M_{a}$ の場合，図一6.1 に示すよ うに循環渦を生じ，下流限界点 $\mathrm{P}$ から上流限界点 $\mathrm{N}$ まで に再循環領域を形成する。循環渦の中心 C 点とノズル口 までの距離 $L_{c}$ は, 吹付材と王縮空気の混合流を単一噴 流（すなわち，上流限界点 $\mathrm{N}$ とノズル口までの距離 $L_{n}$ =0）として扱うと， N 点までは再循環流量 $M_{r}=0$ とな り次式が得られる。

$$
\begin{aligned}
& L_{c}=\frac{1}{2}\left[L_{p}+\frac{b_{s}}{\alpha}\left(\frac{\rho_{s}}{\rho_{a}}\right)^{1 / 2}\right] \ldots \\
& \text { ここで, パラメータ } \theta^{\prime} \text { を } \\
& \theta^{\prime}=\frac{b_{s}}{\alpha}\left(\frac{\rho_{s}}{\rho_{a}}\right)^{1 / 2}
\end{aligned}
$$

と置くと, 基本形式では, $L_{\rho}=L_{0}$ であるから，（3）式 は,

$$
L_{c}=\frac{a}{2}\left(\frac{1}{2 K}+\frac{\theta^{\prime}}{\alpha}\right)
$$

となる。また, 吹出量 $M_{e}$ はホッパ流量 $M_{a}$ と吸込流量, すなわち再循環流量 $M_{r}$ との合成成分であるから，

$$
M_{e}=M_{a}+M_{r}
$$

として，混合方程式を次式で表す。

$$
\frac{M_{e}-M_{a}}{M_{s}}=\frac{\alpha}{4 K \theta^{\prime}}-\frac{1}{2}
$$

吹出量 $M_{e}<$ ホッパ流量 $M_{a}$ の場合, 循環渦はできず
にN点以前に全部混合され尽すことになる。

そこで，吹出量 $M_{e}$ やホッパ流量 $M_{a}$ の大小にかかか らず一般化すれば，吹出量 $M_{e}$ は（6）式で示され，再 循環流量 $M_{\tau}$ の割合は

$$
M_{r} /\left(M_{a}+M_{s}\right)
$$

となるので, パラメータ $\theta^{\prime}$ を

$$
\theta=\frac{M_{s}+M_{a}}{M_{s}} \cdot \theta^{\prime}
$$

と修正する。ここで，（8）式を（7）式に代入すれば,

$$
\frac{M_{e}-M_{a}}{M_{s}+M_{a}}=\frac{\alpha}{4 K \theta}-\frac{M_{s}}{2\left(M_{s}+M_{a}\right)} \text {. }
$$

が得られる。これを次式のように整理する。

$$
M=\frac{\alpha}{2 K} \cdot \frac{1}{\theta}-1
$$

これが本論で提案する吹出量 $M_{e}$ の推定式である。こ こで,パラメータ $M$ およびパラメータ $1 / \theta$ は,

$$
\begin{aligned}
& M=\frac{2 M_{e}-3 M_{a}}{M_{s}+M_{a}} \\
& \frac{1}{\theta}=\frac{M_{s}}{M_{s}+M_{a}} \cdot \frac{a}{d_{e}}
\end{aligned}
$$

である。また， $d_{e}$ は相当ノズルロ径を表し，

$$
d_{e}=b_{s}\left(\frac{\rho_{s}}{\rho_{a}}\right)^{1 / 2}
$$

で示される。

\section{2 吹出量 $M_{e}$ の推定式の検討}

本論で提案した推定式を検討するため, 各吹付ガン器 から得られた吹出量 $M_{e}$ の実験結果と吹付ガン器の各種 吹付要因を用いて解析したデータ結果を表一6.1 に示し た。さらに，各吹付材のパラメータ $M$ とパラメータ $1 / \theta$ を求め, 両者の関係をプロットするとともに，合わ せて推定式 [(10) 式] を図示し，その妥当性流討儿 たのが図一6.2である。それによると，スタッコの $M$ 值はリシンや吹付タイルよりもかなり大きいが，各吹付

表一6.1 推定式によるデー夕解析の結果

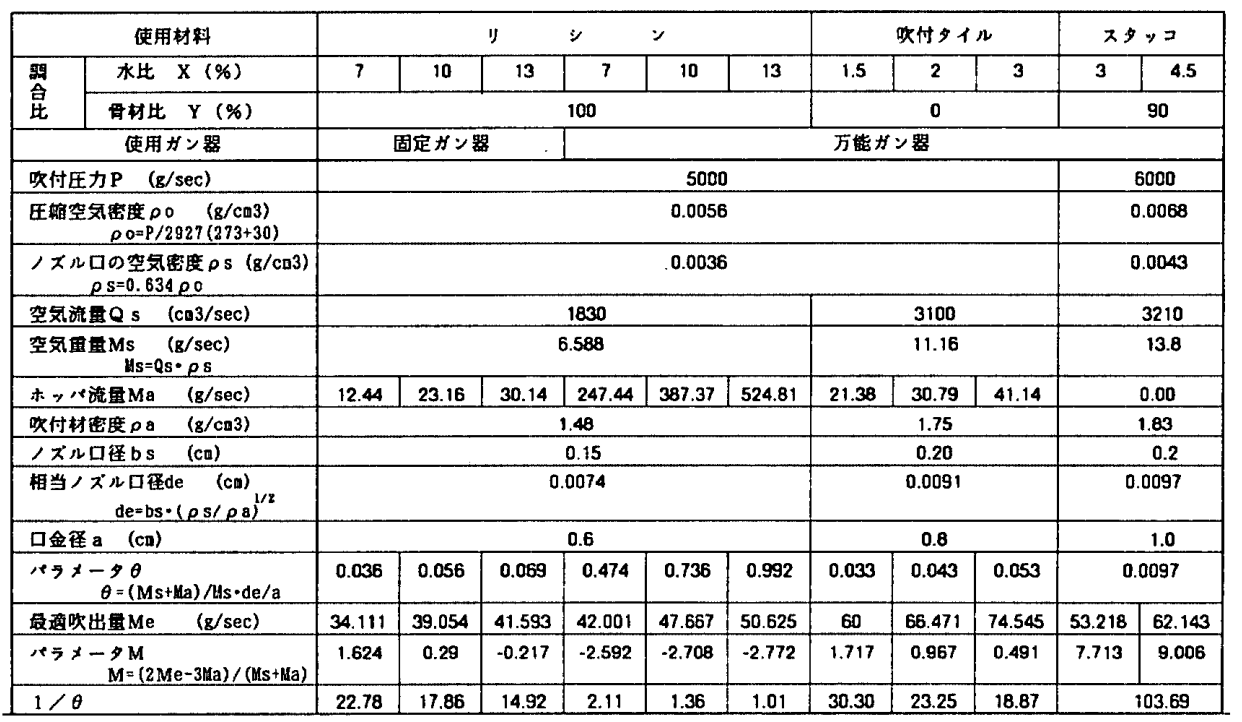




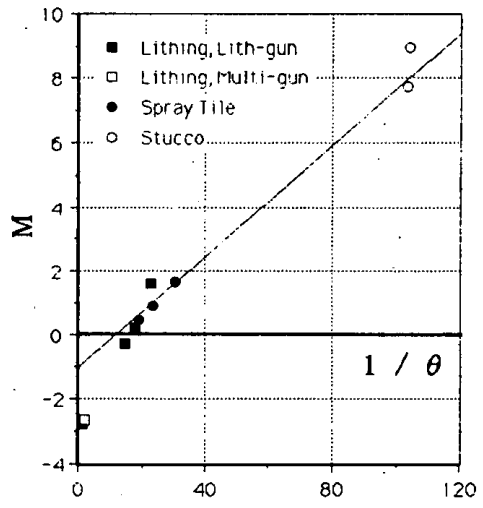

図一6.2 推定式の検討

材とほほぼ推定式の線上にプロットされる。しかし万能 ガン器を用いたリシンのデータのように, ホッパ流量 $M_{a}$ が最適吹出量 $M_{e}$ に対して非常に大きい場合（本実 験では， $M_{a}>6 M_{e}$ の場合）は，必ずしも推定式とは一 致しない。これは噴流が口金の壁面に達するまでに，吹 付材の自重による過度の負珐力が噴流に対して生じるた めに，実際の吹出量は推定式による吹出量よりかなり小 さくなるためと考えられる。

以上から，各吹付材の吹出量 $M_{e}$ は（10）式によって 推定できるが，吹付ガン器の自動化に際しては，各種吹 付要因だけでなく，口金近傍に吹付材を搬送するホッパ 流量 $M_{a}$ の制御も重要な要素となることが分かった。

\section{7. まとめ}

以上, 吹付ガン器からの最適吹出量および各種吹付要 因を実験的に検討し，吹付ガン器からの吹出量の推定式 を理論的かつ定量的に明らかにした。その結果を要約す
る。

（1）吹付ガン器の噴流形式をモデル化し, 吹出効率の 最もよいAタイプを最適吹出量と定め，口金径の大きさ など実際の吹付け施工の現状とも一致することを明らか にした。

（2）各吹付材とも吹出量を最大にする吹付圧力が存在 し，それが最適吹付圧力とも一致する。

（3）粘性の大きい吹付材ほど多くの空気流量を必要と するため，ノズル口径も大きくなるが，多すぎても吹出 量は減少する。

（4）エアーコックによるノズル開口率の調節は吹出量 にあまり影響しないが，吹付仕上げ面のテクスチャーに 影響を及ぼす噴流による吹付材の微粒化には有効であ る。

（5）気液二相の噴流理論を適用して，吹付ガン器から の吹出量を予測する推定式を提案した結果，推定式は ホッパ流量が吹出量より極めて多い場合を除いてほぼ実 験値と一致することが分かった。

なお，本実験の一部は日本建設吹付業連合会（略称， NKF) の協力を得て行ったものである。記して感謝の 意を表します。

\section{参考文献}

1）全国建設吹付技能検定委員会編：建設吹付の施工之管理, p. 92,1975

2）西 忠雄監修：建築仕上材年鑑，工文社，p.797，1986

3）飯沼一男監/田中良一訳：ベア／シガー燃焼の空気力学, 省エネルギセンター, p. 24, 1976

（1990 年 3 月 20 日原稿受理， 1990 年 7 月 21 日採用決定） 